\title{
Pseudomeningocele after Spine Surgery: An Important Cause for Failed Back Syndrome and its Management-A Mini Review
}

\author{
Vibhu Krishnan Viswanathan ${ }^{1 *}$ and Surabhi Subramanian ${ }^{2}$ \\ The Ohio State University, USA \\ Received: January 29, 2018; Published: February 16, 2018 \\ *Corresponding author: Vibhu Krishnan Viswanathan, Clinical Spine Fellow, The Ohio State University, USA, Tel: +16143023859; \\ Email: drvibu007@gmail.com
}

\begin{abstract}
Pseudomeningocele is a known complication after cranial and spinal surgeries. These lesions involve extradural accumulations of cerebrospinal fluid (CSF) [1]. They are mostly asymptomatic; nevertheless can potentially cause serious complications in certain situations [2]. Owing the high incidence of spontaneous regression, most of these lesions are managed conservatively [3]. In symptomatic patients with persistent pseudomeningoceles, a more aggressive approach may be necessary [4]. The current article discusses comprehensively the pathophysiology, diagnostic pearls and management guidelines of these rare pathologies.
\end{abstract}

\section{Introduction}

Pseudomeningoceles are known complications after cranial and spinal surgeries with reported incidence even up to $40 \%$ in certain studies [5]. These lesions involve extradural accumulations of cerebrospinal fluid (CSF) at the operative site [1]. These lesions are mostly asymptomatic; nevertheless can potentially cause serious complications in certain situations [2]. Owing the high chances of spontaneous regression, a majority of these lesions are conservatively managed [3]. In symptomatic patients who have persistent pseudomeningoceles recalcitrant to traditional management, a more aggressive approach may be necessary [4]. The current article discusses comprehensively the pathophysiology, diagnosis and management of these rare pathologies.

\section{Discussion}

Dural tears with intact arachnoidmater results in the development of true cyst lined by arachnoid through the accumulation of CSF by ball-valve mechanism $[4,6]$. Unnoticed dural tear with concomitant arachnoid violation results in oneway CSF flow into the extradural tissue, thereby resulting in a false cyst or pseudomeningocele [4,6]. Pseudomenigocele was first reported by Hyndman \& Gerber [6] in 1946 and were broadly classified by them into two types: iatrogenic and traumatic. These lesions have also been reported in the literature as "meningocele spurious", "pseudocyst" or "false cyst" [7]. Miller et al. [7] further classified these lesions into congenital, iatrogenic and traumatic pseudocysts. Congenital pseudocysts have typically been described in thoracic or thoracolumbar regions, iatrogenic cysts after lumbar laminectomy; while traumatic pseudomeningoceles have mostly been described in cervical spinal segments $[2,8,9]$. The incidence of iatrogenic pseudomeningocele ranges between $0.068 \%$ (as reported by Swanson et al. [10]) to 2\% (as reported by Teplick et al. [11]). Congenital pseudomeningoceles are known to be associated with neurofibromatosis and Marfan's syndrome and as name suggests, exist from birth [8]. Postoperative pseudomeningocele arises following a transgression of duramater and pia-arachnoidmater layers during surgery [11]. When these tears are incompletely closed, CSF extravagates into paraspinal tissues [11]. While CSF may initially be absorbed, progressive reactive changes in the surrounding soft tissues can lead to non-resorption of the fluid. This results in the formation of false pouch containing fluid $[4,7,12]$.

A vast majority of pseudomeningoceles are known to occur in the lumbar spine, possibly due to the following reasons: a. CSF in the lumbar spine exists under a much higher hydrostatic pressure, in comparison with cervical or thoracic spines. B. Lumbar interventional procedures are much more common than thoracic or surgeries $[4,13]$. Hydrocephalus, poor dural closure use of anti-adhesive gels which inhibit fibroblast response and scarring of arachnoidmater have been implicated as possible causes underlying the development of pseudomeningocele [14]. Pseudomeningocele can potentially present in various ways 
including palpable or noticeable mass (fluctuant and expansile on Valsalva maneuver), back or neck pain, radicular or neuropathic pain, neurological deficit, headache (due to reduced intracranial pressure), nausea, vomiting, CSF fistula, psychological trauma to patients and their families, intracranial hypertension, aseptic meningitis or even death $[14,15]$.

Delayed infections have been described after such pseudomeningoceles [4]. The indication for final surgery before pseudomeningocele in the series by Weng et al. [5] included herniated intervertebral disc in $73 \%$, recurrent disc herniation in $9 \%$ and spondylolisthesis with stenosis in $18 \%$. MRI scan is the best imaging modality to identify the extent of pseudomeningocele sac or the fistulous tract in CSF fistula [4]. Pseudomeningoceles larger than $8 \mathrm{~cm}$ have been classified as giant pseudomeningoceles [4]. Weng et al. [4] reported that high body mass index (BMI) is a risk factor for the development of these giant pseudomeningoceles.

The most important steps involved in preventing pseudomeningocele include water-tight closure, tissue glue and duroplasty [4].Optimal treatmentofpseudomeningocelehowever remains controversial $[3,4,7]$. Multiple factors including sac size, location and symptoms determine the course of management of these lesions [16]. Small cysts which are asymptomatic do not need any treatment [2]. Even large pseudomeningoceles tend to scar down and get completely resolved and therefore initial nonsurgical approach is recommended, especially if asymptomatic $[5,17]$. In an article discussing a survey on the management of spinal pseudomeningocele involving 241 neurosurgeons, 90\% preferred non-operative management for at least 7-14 days prior to considering re-exploration [18].

Early surgical drainage is recommended if the pseudomeningocele presents with a CSF fistula [2,11,19]. Symptomatic pseudomeningocele (including major complications like intracranial hypertension, neurological deficits, fistulous tract or infection) which present weeks to months post-operatively, may be treated with surgical intervention $[2,11,19]$. Percutaneous subarachnoid catheters (with or without epidural blood patches) can be employed as a less invasive interventional modality to create CSF diversion, seal the leak and thereby promote healing of the pseudomeningocele or CSF fistula $[4,20]$. Isolated percutaneous injection of epidural blood patch, fibrin glue or fat graft has also been described techniques to cause healing of the pseudomeningocele sac. These techniques affect the dural healing through tamponade effect and enhancing inflammatory response [21]. Surgical treatments for pseudocysts have also been described.

After the pseudomeningocele is surgically explored, nerve roots which have herniated into the sac are gradually dissected free and reduced into the thecal sac. Any fistulous tract is completely excised and the pseudomeningocele sac is extirpated. The dural sac is then closed with direct repair, if feasible or with a dural patch. Additionally, in such situations a subarachnoid catheter may also be passed through skin, muscle and fascial layers for CSF drainage [4,7]. Large dural leaks (especially if lateral) can be difficult to close primarily and therefore be repaired with patch techniques including autologous tissues, sural allografts or fibrin glue [20,22]. Lumbar myofascial flap advancement involving medial advancement of musculocutaneous flaps of paraspinal muscles for the closure and obliteration of pseudomeningocele sacs [23].

\section{References}

1. Couture D, Branch CL (2003) Spinal pseudomeningoceles and cerebrospinal fluid fistulas. Neurosurg Focus 15(6): E6.

2. Lee KS, Hardy IM (1992) Post laminectomy lumbar pseudomeningocele: report of four cases. Neurosurgery 30: 111-114.

3. Solomon P, Sekharappa V, Krishnan V, David KS (2013) Spontaneous resolution of postoperative lumbar pseudomeningoceles: A report of four cases. Indian J Orthop 47(4): 417-421.

4. Weng YJ, Cheng CC, Li YY, Huang TJ, Hsu RWW (2010) Management of giant pseudomeningoceles after spinal surgery. BMC Musculoskeletal Disorders 11: 53.

5. Hawk MW, Kim KD (2000) Review of spinal pseudomeningoceles and cerebrospinal fluid fistulas. Neurosurgical Focus. 9(1): 1-8.

6. Hyndman OR, Gerber WF (1946) Spinal extradural cysts, congenital and acquired: report of cases. J Neurosurg 3(6): 474-486.

7. Miller PR, Elder FW (1968) Meningeal pseudocysts (meningocele spurius) following laminectomy. Report of ten cases. J Bone Joint Surg Am 50(2): 268-276.

8. Sutterlin CE, Grogan DP, Ogden JA (1987) Diagnosis of developmental pathology of the neuraxis by magnetic resonance imaging. J Pediatr Orthop 7(3): 291-297.

9. Kolawole TM, Patel PJ, Naim Ur R (1987) Post-surgical anterior pseudomeningocele presenting as an abdominal mass. Comput Radiol 11(5-6): 237-240.

10. Swanson HS, Fincher EF (1947) Extradural arachnoidal cysts of traumatic origin. J Neurosurg 4(6): 530-538.

11. Teplick JG, Peyster RG, Teplick SK, Goodman LR, Haskin ME (1983) CT Identification of postlaminectomy pseudomeningocele. AJR Am J Roentgenol 140(6): 1203-1206.

12. Pau A (1974) Postoperative "meningocele spurius". Report of two cases. J Neurosurg Sci 18(2): 150-152.

13. Hawk MW, Kim KD (2000) Review of spinal pseudomeningoceles and cerebrospinal fluid fistulas. Neurosurgical Focus 9(1): 1-8.

14. Mehendale NH, Samy RN, Roland PS (2004) Management of pseudomeningocele following neurotologic procedures. Otolaryngol Head Neck Surg 131(3): 253-262.

15. Couture D, Branch CL (2003) Spinal pseudomeningoceles and cerebrospinal fluid fistulas. Neurosurgical Focus. 15(6): 1-5.

16. Nairus JG, Richman JD, Douglas RA (1996) Retroperitoneal pseudomeningocele complicated by meningitis following a lumbar burst fracture. Spine 21(9): 1090-1093.

17. Hadley MN, Carter LP (1985) Sacral fracture with pseudomeningocele and cerebrospinal fluid fistula: case report and review of the literature. Neurosurgery 16(6): 843-846. 
18. Tu A, Tamburrini G, Steinbok P (2014) Management of postoperative pseudomeningoceles: an international survey study. Childs Nerv Syst 30(11): 1791-1801.

19. McCormack BM, Zide BM, Kalfas IH (2005) Cerebrospinal fluid fistula and pseudomeningocele after spine surgery. Spine Surgery, techniques, complication avoidance and management 2: 2033-2042.

20. Pau A (1974) Postoperative "meningocele spurius". Report of two cases. J Neurosurg Sci 18(2): 150-152.

21. Santangelo G, Schmidt T, Gonzalez M, Westesson PL, Silberstein H (2017) Novel Technique of Percutaneous Fat Graft for Repair of

DOI: 10.19080/OAJS.2018.08.555735
Persistent Large Pseudomeningocele. World Neurosurg 106: 1055. e13-1055.e17.

22. Shaffrey CI, Spotnitz WD, Shaffrey ME, Jane JA (1990) Neurosurgical applications of fibrin glue: augmentation of dural closure in 134 patients. Neurosurgery 26(2): 207-210.

23. Misra SN, Morgan HW, Sedler R (2003) Lumbar Myofascial Flap for Pseudomeningocele Repair. Neurosurg Focus 15(3): E13.

\section{Your next submission with Juniper Publishers} will reach you the below assets

- Quality Editorial service

- Swift Peer Review

- Reprints availability

- E-prints Service

- Manuscript Podcast for convenient understanding

- Global attainment for your research

- Manuscript accessibility in different formats

( Pdf, E-pub, Full Text, Audio)

- Unceasing customer service

Track the below URL for one-step submission https://juniperpublishers.com/online-submission.php 